\title{
Phytophthora Root Rot of Blueberry Increases with Frequency of Flooding
}

\author{
Amal de Silva ${ }^{1}$, Keith Patterson ${ }^{2}$, Craig Rothrock ${ }^{3}$, and Ron $\mathrm{McNew}^{4}$ \\ University of Arkansas, Fayetteville, AR 72701
}

Additional index words. waterlogging, irrigation, Vaccinium corymbosum, mulching, Phytophthora cinnamomi, growth

\begin{abstract}
Phytophthora root rot is a severe disease on blueberry (Vaccinium corymbosum L.) in poorly drained soils. Little is known about how mulching and frequent waterlogging affect disease severity in blueberries. Phytophthora cinnamomi Rands was grown on rice hulls, which were incorporated into the soil at the rate of $10 \%$ (v:v). Waterlogging conditions were imposed for 48 hours 1 week after planting on mulched and nonmulched blueberry plants at weekly, biweekly, and monthly intervals for a total of 3 months. Control plants were not subjected to flooding. The severity of Phytophthora root rot increased with time. Significant linear relationships were found between flooding interval and disease severity rating of shoot, percentage of root infection, and shoot and root dry weights of plants. Disease symptoms were minimal in control plants, but shoot disease rating and percentage of root infection were high in mulched and nonmulched plants that were flooded every week. Shoot and root dry weights were higher in 1997 than in 1996. In 1996, mulched plants had higher shoot dry weights than did nonmulched plants. Disease incidence was higher with weekly and biweekly flooding than with monthly or no flooding. However, mulching did not affect root infection.
\end{abstract}

Phytophthora root rot of highbush blueberry is caused by Phytophthora cinnamomi Rands (Clayton and Haasis, 1964; Royle and Hickman, 1963). The disease is prevalent in northwest Arkansas, Missouri, and Oklahoma, and affects all the cultivars grown in Arkansas, where it can be severe. The disease has also been reported in New Jersey and in Oregon. The foliar symptoms include chlorosis, reddening, and defoliation. Infected roots become necrotic. Milholland and Galletta (1967) noted that rabbiteye blueberry (Vaccinium ashei Reade) cultivars were more tolerant of Phytophthora root rot than were highbush blueberries. Sterne (1982) reported that the problem was associated with plantings on poorly drained soils. Wet soil conditions stimulate germination of chlamydospores and sporangia (Sterne et al., 1977), and flooding increases disease severity (MacDonald and Duniway, 1978). A flooding period of $48 \mathrm{~h}$ increased disease severity of Phytophthora sp. on Mahaleb cherry (Prunus mahaleb L.) seedlings (Wilcox and Mircetich, 1985), and repeated flooding increased disease caused by Phytophthora in pepper (Piper nigrum L.) (Bowers and Mitchell, 1990).

\footnotetext{
Received for publication 13 July 1998. Accepted for publication 5 Nov. 1998. The cost of publishing this paper was defrayed in part by the payment of page charges. Under postal regulations, this paper therefore must be hereby marked advertisement solely to indicate this fact.

${ }^{1}$ Graduate Student, Dept. of Horticulture.

${ }^{2}$ Associate Professor, Dept. of Horticulture. Present address: Crop Science Dept., California Polytechnic State Univ., San Luis Obispo, CA 93407.

${ }^{3}$ Professor, Dept. of Plant Pathology.

${ }^{4}$ Professor and Department Head, Dept of Agricul-
} tural Statistics.
Sandy loams, peats, or well-structured loams are recommended for blueberries (Eck, 1988). Unfortunately, soils in Arkansas and many other blueberry-producing states are not ideal. Therefore, soil modifications are necessary. For successful cultivation, mulching with sawdust and wood chips is recommended for plantings in Arkansas (Moore, 1990). Most of the commercial plantings in Arkansas are mulched to a depth of 7.5 to $15 \mathrm{~cm}$, which increases water-holding capacity of the soil, restricts fertilizer leaching, and suppresses weed growth. This practice, however, may predispose plants to root rot. Sterne (1982) described two patterns of distribution of diseased plants in northwest Arkansas: some were associated with low, poorly drained areas, and others were scattered throughout the field. The above-mentioned areas may experience flooding, especially in the spring, because of a high water table and high rainfall. Sterne (1982) noted that the disease has rapidly and extensively spread among blueberry plantings. The pathogen is widely distributed in soils of Arkansas and adjoining areas, and diseased plants have been observed even in mineral soils when irrigation is excessive (J. Moore, personal communication). Zentmyer and Mircetich (1966) showed that the pathogen can survive for several years in soil in the absence of a host. Phytophthora cinnamomi might be a typical component of soils of northwest Arkansas, which would favor the development of the disease. The objectives of this study were to determine the influence of flooding interval on disease severity and root infection of nonmulched and mulched blueberry plants.

\section{Materials and Methods}

Preparation of inoculum. Diseased blueberry plants were taken from an infested field and the root pieces were plated on a medium (PARPH) consisting of cornmeal agar containing pimaricin $(2.5 \%)$, ampicillin (250 $\left.\mathrm{mg} \cdot \mathrm{L}^{-1}\right)$, rifampicin $\left(1 \mathrm{mg} \cdot \mathrm{L}^{-1}\right)$, pentachloronitrobenzene $(\mathrm{PCNB})\left(134 \mathrm{mg} \cdot \mathrm{L}^{-1}\right)$, amended with $71.4 \mathrm{mg}$ of hymexazol ( $75 \%$ w.p.) (Jeffers and Martin, 1986). Phytophthora cinnamomi was isolated and identified, and grown on $1 \mathrm{~L}$ of a liquid medium containing $163 \mathrm{~mL}$ V-8 juice (Campbell Soup Co., Camden, N.J.), $2.4 \mathrm{~g}$ calcium carbonate, $12 \mathrm{~g}$ agar (Difco Laboratories, Detroit). The fungus was subsequently grown on rice hulls according to Sterne (1982).

Treatments. Soil (Captina silt loam) (1 kg) was brought to field capacity with water and pasteurized for 4 min using a 800 -W microwave oven. Rice hulls containing the fungal inoculum were incorporated into soil at the rate of $10 \%$ (v:v) immediately prior to planting. One-year-old, bare-rooted, uniform-sized 'Bluecrop' blueberry plants were planted in 15 -cm-diameter pots containing the 10 soil : 1 inoculum mixture (v/v). Flooding treatments on both mulched and nonmulched plants were begun 1 week after planting and consisted of either weekly, biweekly, or monthly flooding for $48 \mathrm{~h}$ during a 3 -month growing period. A mulch of fresh pine wood chips and sawdust was used to a depth of $7.5 \mathrm{~cm}$ on the soil surface. Water level during flooding was maintained at $\approx 1.2 \mathrm{~cm}$ above the soil surface. Control plants were not flooded. The study was initiated on 28 Mar. 1996 and repeated 24 Mar. 1997 with a different set of plants. Treatments were replicated five times in a randomized complete-block design. Maximum temperatures in the greenhouse during the experimental period were $32{ }^{\circ} \mathrm{C}$ in 1996 , and $37^{\circ} \mathrm{C}$ in 1997; minimum temperature was $15^{\circ} \mathrm{C}$ in both years. Maximum temperature of the flooded soil was 30 to $32{ }^{\circ} \mathrm{C}$. Plants were grown for 3 months and fertilized weekly with Peters (20N-8.8P-16.6K) (United Industries Corp., St. Louis) at the rate of $200 \mathrm{mg} \cdot \mathrm{L}^{-1} \mathrm{~N}$. Plants were watered every other day in 1996 , and every day in 1997 because of high evapotranspiration.

Plant measurements. Shoots were rated for symptoms monthly according to a scale developed by Milholland (1975). The rating scale was $0=$ healthy; 1 = slight chlorosis, growth good; 2 = moderate chlorosis, growth fair; $3=$ severe chlorosis, reddening of lower leaves, growth fair to poor; 4 = reddening of leaves, defoliation, growth poor; $5=$ plants dead. Plants were harvested after 3 months. Percent infection of roots was determined at harvest by plating one 2-cm segment from each of 20 roots taken randomly from all plants on PARPH medium. After root pieces were taken, the plants were dried at $80^{\circ} \mathrm{C}$ for $3 \mathrm{~d}$, and shoot and root dry weights recorded.

Data analysis. The SAS general linear model procedure was used to analyze the data and perform regression analysis (SAS Institute, 1996). Data for both years were combined for analysis. The means were separated by least significant difference according to the significance of the $F$ values for main effects and interactions. 


\section{Results and Discussion}

Disease progress. Leaf symptoms increased with flooding over the 3-month growing period in both years of the experiment. This finding corroborates earlier work by Erb et al. (1987) on blueberry. In 1996, the linear component was significant $(P \leq 0.05)$ for all treatments except for the nonflooded control and nonmulched plants flooded monthly (Fig. $1 \mathrm{~A}$ and B). In 1997, the change in shoot disease index over time in all mulched plants except the control was a quadratic (Fig. $1 \mathrm{C}$ and D). However, in all nonmulched treatments the change was linear with time. Our findings also agree with those of Wilcox and Mircetich (1985), who found that a 48-h flooding period increased disease severity on cherries. With weekly flooding, symptoms developed quickly and some plants died (two plants in 1996 and one in 1997). Bowers and Mitchell (1990) also reported the death of pepper seedlings subjected to periodic flooding of infested soil. Symptoms on nonflooded control plants were minimal and limited to random chlorosis of leaves. In 1997, with the monthly flooding interval, symptom expression was greater in mulched than in nonmulched plants, with the latter being no different from the controls.

Effect of flooding interval on disease development. Disease ratings of shoots and percentage root infection increased as the interval between floodings decreased $(P \leq 0.01)$ (Table $1)$. The relationship between flooding interval was linear for both shoot disease rating and root infection $(P \leq 0.01)$. Although the yearly component was significant for root infection $(P \leq 0.008)$, it was nonsignificant for shoot disease rating, perhaps because of the difference between time of symptom expression and the level of infection. In nonmulched and mulched plants, mean shoot disease ratings were 3.4 and 3.2, respectively, with weekly flooding vs. 0.8 and 0.9 , respectively, in the nonflooded treatments (Table 2). The disease rating was also higher with weekly than with biweekly flooding in nonmulched plants. However, this difference was less pronounced and not statistically significant with mulched plants. Higher disease symptoms with biweekly flooding could have resulted from high moisture conservation by the mulch. With monthly flooding, mulched plants had more severe disease symptoms than did nonmulched plants. With weekly flooding, $64 \%$ of sampled roots were infected. However, the difference in incidence of root infection with weekly vs. biweekly flooding was nonsignificant (data not shown). The nonflooded control had the lowest incidence. Mean root infection across all treatments was $56 \%$ in 1997 vs. $45 \%$ in 1996 , perhaps because the temperature in the greenhouse was higher in the second season and water was applied daily. Low infection in the control treatments agrees with the results of Ploetz and Schaffer (1989) on avocado. Root rot susceptibility in blueberry may be related to Phytophthora zoospore attraction (Erb et al., 1986). Thus, increased root rot with weekly and biweekly flooding could have been due to frequent zoospore discharge and infection
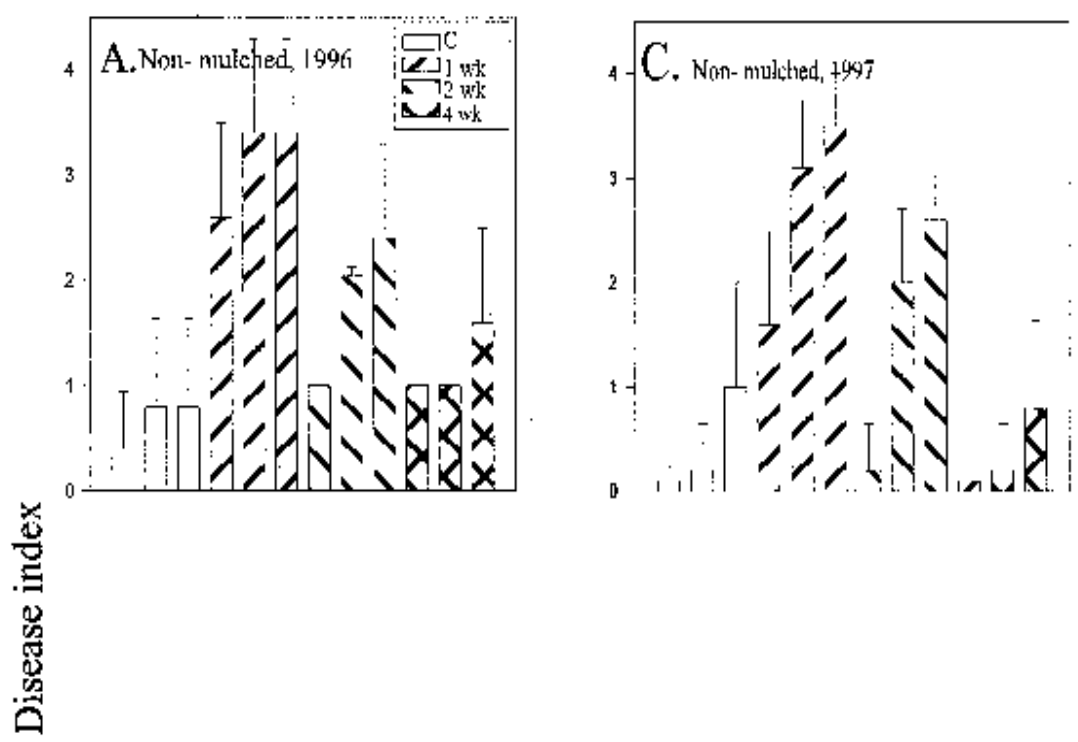

4. D. Mulched, 1997

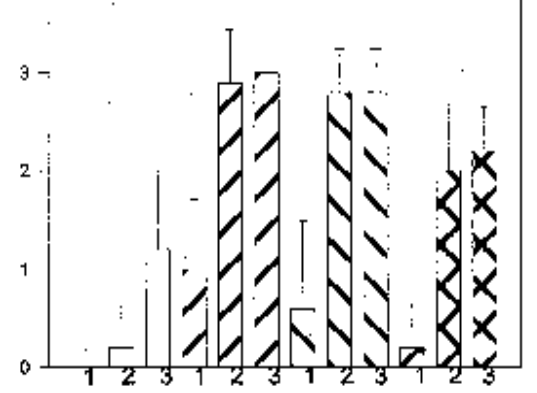

\section{Months}

Fig 1. Effects of frequency of flooding (control, 1, 2, or 4 weeks) on disease progress in shoots of (A and C) nonmulched and (B and D) mulched blueberry plants infected with P. cinnamomi in 1996 and 1997. Data recorded 1,2, and 3 months after start of experiment. Disease index is : $0=$ healthy $; 1=$ slight chlorosis, growth good ; $2=$ moderate chlorosis , growth fair $; 3=$ severe chlorosis, reddening of lower leaves, growth fair to poor ; $4=$ reddening of leaves, defoliation, growth poor $; 5=$ plants dead. $\mathrm{N}=$ nonmulched; $\mathrm{M}=$ mulched; $\mathrm{C}=$ control; $\mathrm{wk}=$ week. Vertical bars represent $\pm \mathrm{sD}$.

Table 1. Probability values, based on analysis of variance of shoot disease rating, root infection, and dry weight of blueberry plants infected with $P$. cinnamomi as affected by flooding intervals over 2 years.

\begin{tabular}{|c|c|c|c|c|c|}
\hline \multirow[b]{2}{*}{ Source $y$} & & \multirow{2}{*}{$\frac{\text { Disease rating }^{2}}{\text { Shoot }}$} & \multirow{2}{*}{$\frac{\text { Infection }(\%)^{2}}{\text { Root }}$} & \multicolumn{2}{|c|}{ Dry $w^{2}$} \\
\hline & & & & Shoot & Root \\
\hline Year & & 1.0 & 0.008 & 0.004 & 0.04 \\
\hline Rep (year) & & 0.15 & 0.550 & 0.06 & 0.182 \\
\hline FI & & 0.0001 & 0.0001 & 0.0001 & 0.0001 \\
\hline M & & 0.06 & 0.991 & 0.014 & 0.015 \\
\hline $\mathrm{FI} \times \mathrm{M}$ & & 0.03 & 0.221 & 0.017 & 0.04 \\
\hline Year $\times$ FI & & 0.142 & 0.227 & 0.107 & 0.242 \\
\hline Year $\times M$ & & 0.75 & 0.549 & 0.006 & 0.209 \\
\hline \multirow{2}{*}{$\begin{array}{l}\text { Year } \times \text { FI } \times M \\
\text { FI }\end{array}$} & & 0.73 & 0.89 & 0.108 & 0.774 \\
\hline & Linear & 0.0001 & 0.0001 & 0.002 & 0.0001 \\
\hline
\end{tabular}

${ }^{2}$ The disease rating, percentage of colonization, and dry weights were taken on all plants in each replication on 30 June 1996 and 26 June $1997(n=10)$.

${ }^{\mathrm{y}} \mathrm{FI}=$ Flooding interval; $\mathrm{M}=$ mulch. 
Table 2. Effect of frequency of flooding on mean shoot disease rating and dry weight of blueberry plants infected with $P$. cinnamomi averaged over 2 years.

\begin{tabular}{lcccccccc}
\hline & \multicolumn{2}{c}{ Shoot disease rating } & & \multicolumn{2}{c}{ Shoot dry wt $(\mathrm{g})^{\mathrm{z}}$} & & \multicolumn{2}{c}{ Root dry wt $(\mathrm{g})^{\mathrm{z}}$} \\
\cline { 2 - 3 } Fonmulched & Mulched & & Nonmulched & Mulched & & Nonmulched & Mulched \\
\hline Control & $0.80 \mathrm{c}^{\mathrm{x}}$ & $0.90 \mathrm{c}$ & & $8.2 \mathrm{a}^{\mathrm{w}}$ & $12.6 \mathrm{a}^{\mathrm{w}}$ & & $8.6 \mathrm{ab}^{\mathrm{w}}$ & $18.0 \mathrm{a}^{\mathrm{w}}$ \\
$1 \mathrm{Wk}$ & $3.4 \mathrm{a}$ & $3.2 \mathrm{a}$ & & $5.1 \mathrm{~b}$ & $6.7 \mathrm{~b}$ & & $5.0 \mathrm{~b}$ & $4.4 \mathrm{~b}$ \\
$2 \mathrm{Wk}$ & $2.5 \mathrm{~b}$ & $2.7 \mathrm{ab}$ & & $9.1 \mathrm{a}$ & $8.1 \mathrm{~b}$ & & $8.6 \mathrm{ab}$ & $8.8 \mathrm{~b}$ \\
$4 \mathrm{Wk}$ & $1.2 \mathrm{c}^{\mathrm{w}}$ & $2.3 \mathrm{~b}^{\mathrm{w}}$ & & $9.6 \mathrm{a}$ & $10.6 \mathrm{a}$ & & $12.4 \mathrm{a}$ & $16.8 \mathrm{a}$
\end{tabular}

${ }^{2}$ Disease ratings and dry-weight measurements taken on all plants per replication on 30 June 1996 and 26 June 1997.

${ }^{\mathrm{y}} \mathrm{FI}=$ Frequency of flooding $(\mathrm{n}=10)$.

${ }^{x}$ Mean separation within columns by $\mathrm{LSD}_{0.05}$.

${ }^{w}$ Difference between nonmulched and mulched plants significant at $P \leq 0.05$.

of the roots (Wilcox and Mircetich, 1985).

Blueberry growth. Mulching increased shoot and root dry weight, as shown by Clark and Moore (1991) (Table 1). When the mulch $\times$ flooding interval interaction for shoot and root dry weight was averaged over years (Table 2 ), mulched control plants had higher shoot and root dry weights than did similar plants flooded weekly and biweekly. However, root dry matter did not differ significantly between weekly and biweekly flooding, perhaps because of the high infection level of roots flooded biweekly. Shoot and root dry weights were greater in the mulched (12.6 and $18 \mathrm{~g}$, respectively) than in the nonmulched control ( 8.2 and $8.6 \mathrm{~g}$, respectively). Shoot and root dry weights following monthly flooding were comparable with those of the nonflooded control. Shoot dry weights were significantly lower in both nonmulched and mulched plants in 1996 than in 1997 (Table 3). However, shoot dry matter was lower in nonmulched $(4.8 \mathrm{~g})$ than in mulched plants $(8.3 \mathrm{~g})$ in 1996 . Root dry matter was greater in 1997 than in $1996(P \leq$ 0.05) (data not shown).

Shoot disease rating, percent infection, and shoot and root dry weights were all higher in 1997 than in 1996. Spiers (1983) reported that mulching could be replaced by increasing the frequency of watering in rabbiteye blueberries. Our findings corroborate this observation. At higher moisture levels, nonmulched plants had higher shoot dry weight in 1997 than in 1996, and the values were comparable with those of mulched plants. Frequent watering induced stunting and severe disease symptoms. Davies and Flore (1986) reported that flooding every $2 \mathrm{~d}$ did not affect stomatal conductance or carbon assimilation in highbush blueberries. They observed that sensitivity to flooding was due more to Phytophthora root rot than to any physiological factors.

Frequent flooding increased disease severity, but mulching did not. This contradicts the observations of Merwin (1992) for the incidence of Phytophthora crown and root rot in apple (Malus $\times$ domestica Borkh.) under straw mulch. Although mulching reportedly reduces
Phytophthora capsici infection of bell pepper (Roe et al., 1994), it did not suppress the disease in our study. In blueberry production fields, high moisture levels are needed for maximum yields. Blueberry-growing areas in Arkansas have relatively shallow soil with compacted clay layers (Sterne, 1982); thus, the disease may spread during the spring with high rainfall. Management practices should be varied accordingly. Our study indicates that if there are periods of flooding, infection by Phytophthora may be severe following frequent application of water. Therefore, irrigation should be reduced in these areas. However, if the field is not mulched, frequent application of water may favor growth. Maloney et al. (1993) found a dramatic reduction of Phytophthora root rot of raspberry in raised beds. Thus, in areas where high percentages of clay occur in the soil, blueberries should be grown in raised beds to a height of $20 \mathrm{~cm}$, which would facilitate drainage and minimize disease severity.

\section{Literature Cited}

Bowers, J.H. and D.J. Mitchell. 1990. Effect of soilwater matric potential and periodic flooding on mortality of pepper caused by Phytophthora capsici. Phytopathology 80:1447-1450.

Clark, J.R. and J.N. Moore. 1991. Southern highbush blueberry response to mulch. HortTechnology 1:52-54.

Clayton, C.M. and F.A. Haasis. 1964. Blueberry root-rot caused by Phytophthora cinnamomi in North Carolina. Plant Dis. Rptr. 48:460-461.

Davies, F.S. and J.A. Flore. 1986. Gas exchange and flooding stress of highbush and rabbiteye blueberries. J. Amer. Soc. Hort. Sci. 111:565-571.

Eck, P. 1988. Blueberry science. Rutgers Univ. Press, New Brunswick, N.J.

Erb, W.A., J.N. Moore, and R.E. Sterne. 1986. Attraction of Phytophthora cinnamomi zoospores to blueberry roots. HortScience 21:1361-1363.

Erb, W.A., J.N. Moore, and R.E. Sterne. 1987. Response of blueberry cultivars to inoculation with Phytophthora cinnamomi Rands zoospores. HortScience 22:298-300.

Jeffers, S.N. and S.B. Martin. 1986. Comparison of two media selective for Phytophthora and Pythium species. Plant Dis. 70:1038-1043.
Table 3. Effect of mulching on mean shoot dry weight of blueberry plants infected with $P$. cinnamomi across all flooding intervals in 1996 and 1997.

\begin{tabular}{lcc}
\hline & \multicolumn{2}{c}{ Shoot dry wt $(\mathrm{g})^{\mathrm{z}}$} \\
\cline { 2 - 3 } Year & Nonmulched & Mulched \\
\hline 1996 & $4.8 \mathrm{~b}^{\mathrm{y}, \mathrm{x}}$ & $8.3 \mathrm{~b}^{\mathrm{x}}$ \\
1997 & $11.2 \mathrm{a}$ & $10.6 \mathrm{a}$
\end{tabular}

${ }^{2}$ Measurements taken on all five replications on 30 June 1996 and 26 June 1997.

${ }^{y}$ Mean separation within columns by $\operatorname{LSD}_{0.05}$.

${ }^{x}$ Difference between nonmulched and mulched plants significant at $P \leq 0.05$ in 1996 .

MacDonald, J.D. and J.M. Duniway. 1978. Influence of matric and osmotic component of water potential on zoospore discharge in Phytophthora. Phytopathology 68:751-755.

Maloney, K.E., W.F. Wilcox, and J.C. Sanford. 1993. Raised beds and metalaxyl for controlling Phytophthora root rot of raspberry. HortScience 28:1106-1108.

Merwin, I.A., W.F. Wilcox, and W.C. Stiles. 1992. Influence of orchard ground cover management on the development of Phytophthora crown and root rots of apple. Plant Dis. 76:199-205.

Milholland, R.D. 1975. Pathogenicity and histopathology of Phytophthora cinnamomi on highbush blueberry. Phytopathology 65:789-793.

Milholland, R.D. and G.J. Galletta. 1967. Relative susceptibility of blueberry cultivars to Phytophthora cinnamomi. Plant Dis. Rptr. 51:998-1001.

Moore, J.N. 1990. Mulching blueberries: Fact vs. fiction, p. 59-63. In: Proc. 1990 Missouri Small Fruit Conf.

Ploetz, R.C. and B. Schaffer. 1989. Effects of flooding and Phytophthora root rot on net gas exchange and growth of avocado. Phytopathology 79:204-208.

Roe, E.N., P.J. Stoffella, and H.H. Bryan. 1994. Growth and yields of bell pepper and winter squash grown with organic and living mulches. J. Amer. Soc. Hort. Sci. 119:1193-1199.

Royle, D.J. and C.J. Hickman. 1963. Phytophthora cinnamomi on highbush blueberry. Plant Dis. Rptr. 47:266-268.

SAS Institute. 1996. SAS user's guide. SAS Inst., Cary, N.C.

Spiers, J.M. 1983. Irrigation and peat moss for the establishment of rabbiteye blueberries. HortScience 18:936-937.

Sterne, R.E. 1982. Phytophthora root rot of blueberry in Arkansas. Plant Dis. 66:604-605.

Sterne, R.E., G.A. Zentmyer, and M.R. Kaufmann. 1977. The influence of matric potential, soil texture, and soil amendment on root disease caused by Phytophthora cinnamomi. Phytopathology 67:1495-1500.

Wilcox, W.F. and S.M. Mircetich. 1985. Effects of flooding duration on the development of Phytophthora root and crown rots of cherry. Phytopathology 75:1451-1455.

Zentmyer, G.A. and S.M. Mircetich. 1966. Saprophytism and persistence in soil by Phytophthora cinnamomi. Phytopathology 56:710-712. 